\title{
Ophthalmia nodosa and the oculoglandular syndrome of Parinaud*
}

\author{
XAVIER MARTIN, SYLVIE UFFER, AND CLAUDE GAILlOUd \\ From the University Eye Clinic, Lausanne, Switzerland
}

SUMmary We present a case of ophthalmia nodosa and Parinaud's oculoglandular syndrome in a patient scratched by a cat six and a half months previously and who gave a positive result to an antigen test for cat scratch disease. In conjunctival swabs were also found urticarial hairs, tracheal fragments, processionary caterpillar oenocytes, and a grain of pollen. The pathogenic part played by each of these foreign bodies is discussed, as well as the possibility of the oculoglandular syndrome being due to the reactivation of a latent virus, the organism of cat scratch disease. So far as we know, this work provides the first description of the association of ophthalmia nodosa with the oculoglandular syndrome of Parinaud.

The hairs of certain insects or plants can penetrate the conjunctiva and the cornea to produce an inflammation named ophthalmia nodosa. The severe ocular reaction is the combined effect of two separate components, one mechanical and the other toxic.' The term 'ophthalmia nodosa' derives from the nodular conjunctival reaction. ${ }^{2}$ Depending on the regions, the cause of the ophthalmia nodosa is mainly the needles of plants, such as the common burdock, ${ }^{134}$ or urticarial hairs of some caterpillars. ${ }^{5-7}$ According to Watson and Sevel ${ }^{8}$ only six varieties of caterpillars are known to cause ophthalmia nodosa. Macrothylacia rubi and Arctia caja are found only in the British Isles, while Thaumetopoea pityocampa Schiff (pine processionary), Thaumetopoea jordana, Isia isabella, and Dendrolimus pini may be found in other countries. Two other species may be added to these, namely Thaumetopoea pinivora, another pine processionary, and Thaumetopoea processionnea L., an oak processionary. ${ }^{9}$ Furthermore, the oak processionary is supposed to have a greater urticarial impact than the pine caterpillar. ${ }^{10}$

The oculoglandular syndrome ${ }^{11}$ is defined as a unilateral granulo-conjunctivitis associated with one or several pretragal and/or submaxillary adenopathies. Although in several cases the patients either

*A part of this work was presented as a poster at the SSO meeting, Lausanne, 1984.

Correspondence to Dr X Martin, Universitäts-Augenklinik, Mittlere Strasse 91, 4056 Basel, Switzerland. had been scratched or had simply come into contact with cats, many other causes of the disease have been reported (Table 1).

The explanation for the unusual association in the same patient of an ophthalmia nodosa and of an oculoglandular syndrome is suggested from histopathological examination of the lesions.

Table 1 Causes of the oculoglandular syndrome

\begin{tabular}{|c|c|}
\hline Diseases & Responsible agents \\
\hline \multicolumn{2}{|l|}{ Frequent } \\
\hline Cat scratch disease & Unknown \\
\hline Tularaemia & Francisella tularensis \\
\hline Sporotrichosis & Sporothrix schenkii \\
\hline \multicolumn{2}{|l|}{ Occasional } \\
\hline Tuberculosis & Mycobacterium \\
\hline Syphilis & Treponema pallidum \\
\hline Coccidioidomycosis & Coccidioides immitis \\
\hline \multicolumn{2}{|l|}{ Rare } \\
\hline Pasteurellosis & $\begin{array}{l}\text { Pasteurella septica Yersinia pseudo- } \\
\text { tuberculosis, y. enterocolitica }\end{array}$ \\
\hline Equinia & Actinobacillus mallei \\
\hline Chancroid & Haemophilus ducreyi \\
\hline Venereal lymphogeanuloma & Chlamydia trachomatis L, L2, L3 \\
\hline Listeriosis & Listeria monocytogenes \\
\hline Actinomycosis & Actinomyces israelii \\
\hline Blastomycosis & Blastomyces dermatidis \\
\hline Mumps & Paramyxovirus \\
\hline Infectious mononucleosis & Epstein-Barr herpes virus \\
\hline Spotted fever & Rickettsia conorii \\
\hline
\end{tabular}

Modified according to Chin and Hyndiuk. ${ }^{24}$ 

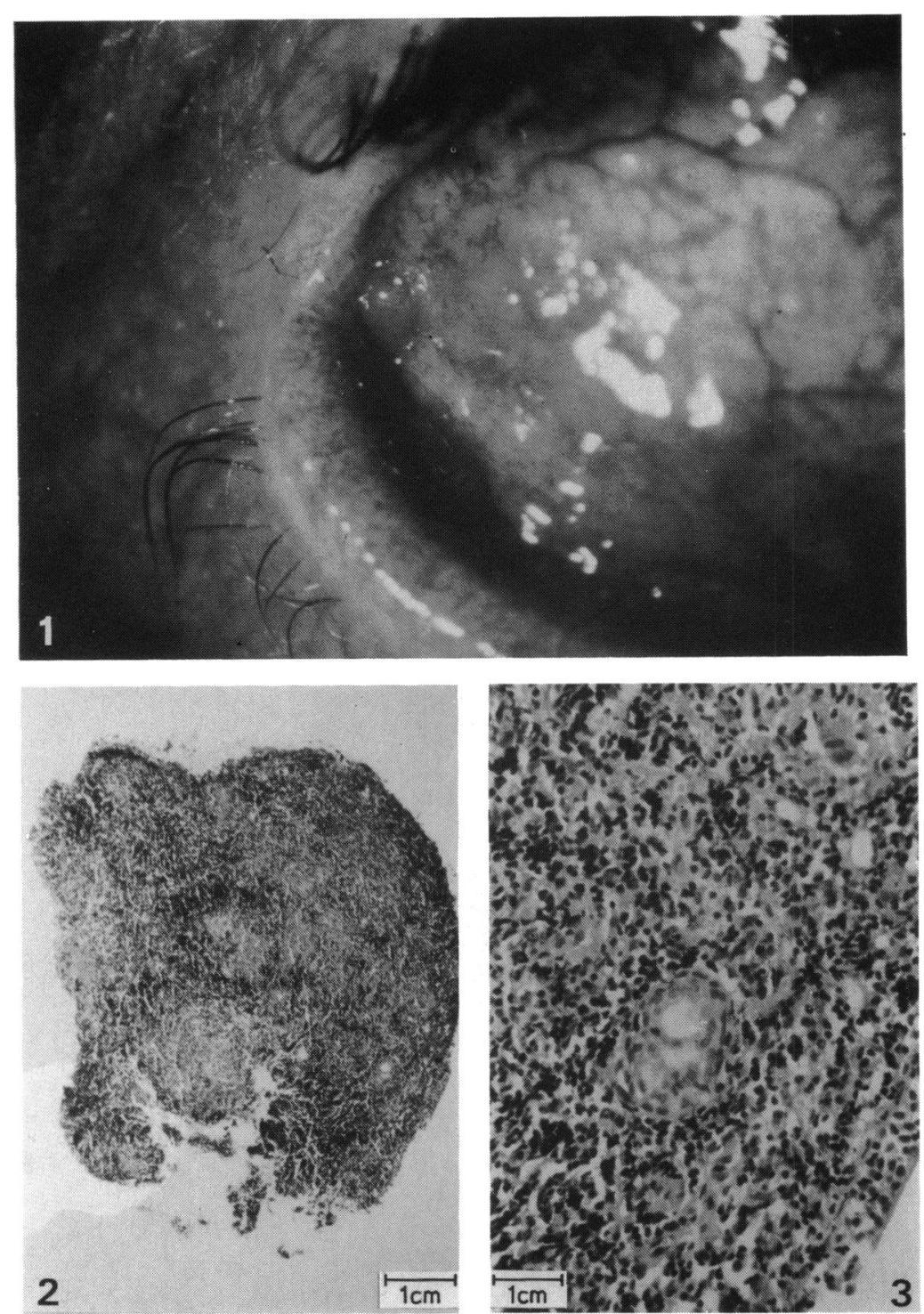

Fig. 1 Characteristic aspect of the nodular lesions in ophthalmia nodosa.

Fig. 2 Macroscopic, nodular conjunctival lesion. (H-E, scale $=200 \mu \mathrm{m}$ ).

Fig. 3 Typical nodule in ophthalmia nodosa, centred by a caterpillar hair. Same slide as in Fig. 2. $(H-E$, scale $=50 \mu \mathrm{m})$.

\section{Case report}

CASE HISTORY AND STATUS OF THE EYE A 56-year-old man, without a history of ocular disease, came to our outpatient department on 28 February 1983 suffering from unilateral conjunctivitis of the right eye since 21 February 1983 . On examination, we observed conjunctival injection and marked inferior temporal chemosis but an unscathed cornea. The condition deteriorated in spite of an initial treatment with neomycin and bacitracin, followed by neomycin, polymyxin $B$, and dexamethasone. Taking a second case history revealed that six and a half months earlier the patient had been scratched on the forehead and right eyelid by a cat. Around mid February 1983, a few days before the beginning of the conjunctivitis of the right eye, the patient had pulled down a caterpillar nest from a pine in his garden without taking any precautions.

On 18 March 1983, the right pretragal gland, palpable since the beginning of the disease, had become very enlarged and painful, measuring 5 by 7 $\mathrm{cm}$; the conjunctival lesion of the right eye remained unchanged. Various investigations (general, ear, nose, and throat, blood tests) all gave normal results. The patient's condition did not improve in spite of 
Fig. 4 Tracheal fragments of the processionary caterpillar found in the conjunctival lesion. $(H-E$, scale $=55 \mu \mathrm{m}$ ).

Fig. 5 Tracheal fragments and eight oenocytes of the processionary caterpillar. Same slide as in Fig. 4. $(H-E$, scale $=20 \mu m)$.

Fig. 6 Grain of pollen found in the conjunctival lesion. $(H-E$, scale $=30 \mu \mathrm{m}$ ).
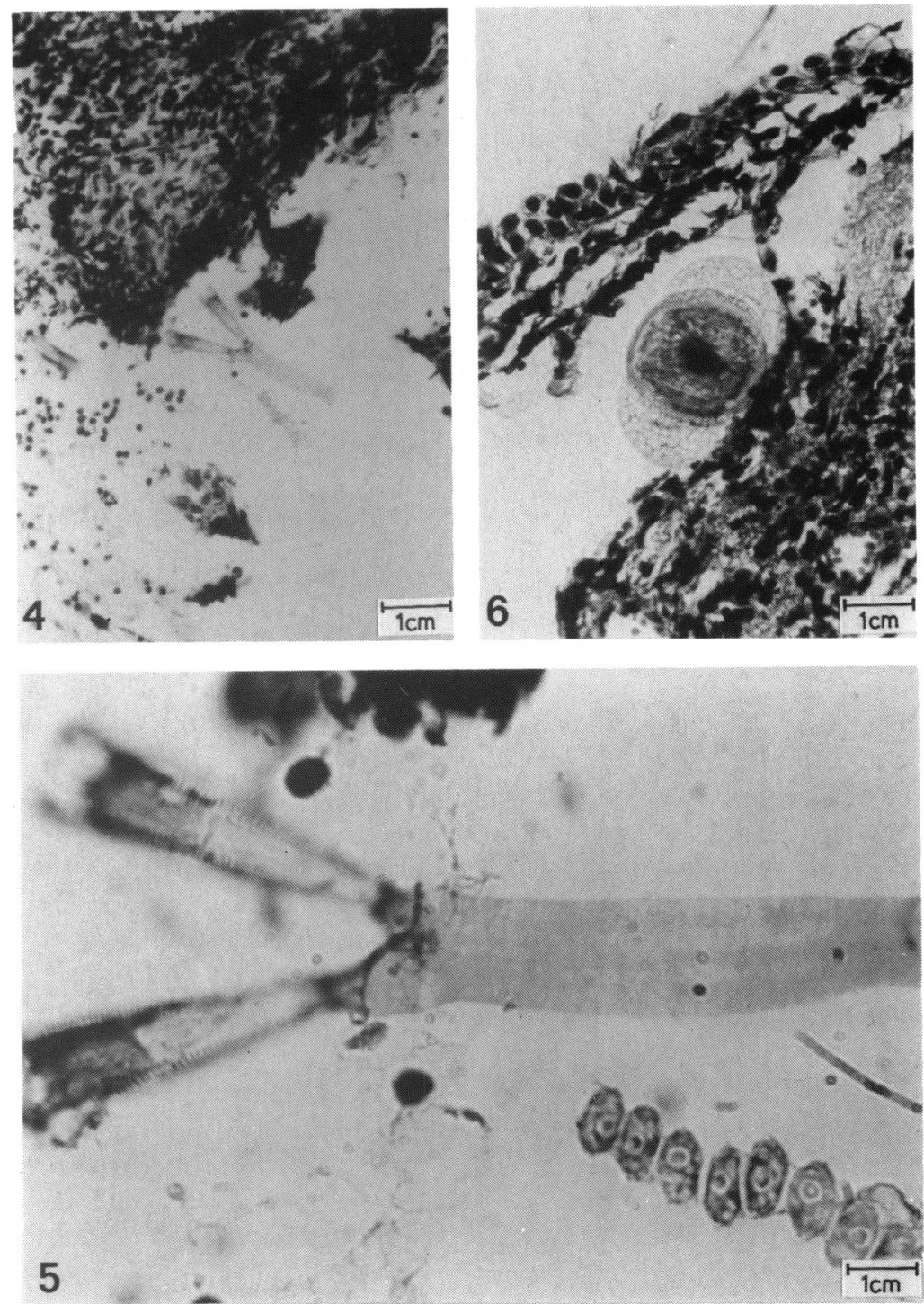

local and general antibiotic therapy (Spiramycin $2 \mathrm{~g}$ daily). Consequently on 29 March 1983 we performed an incision and drainage of the swollen gland. Examination (aerobic and anaerobic cultures) proved negative, and histological examination led us to the conclusion of reticulo-abscess lymphadenitis compatible with cat scratch disease. On 1 June 1983 we excised the conjunctival lesion, which had not regressed in spite of local treatment (Fig. 1). Histopathological examination showed the presence of granulomas containing foreign bodies, caterpillar hairs, tracheal fragments, caterpillar oenocytes, and a grain of pollen. On 13 June 1983 a thorough examination of the eye showed no other ocular lesion. On 20 June 1983 an antigen test for cat scratch disease proved to be positive after 48 hours.

At follow-up on 25 June 1983 the patient was regarded as cured.

\section{PATHOLOGY OF THE CONJUNCTIVAL LESION}

Macroscopically. Characteristic nodular lesion measuring $5 \mathrm{~mm}$ in length, $2 \mathrm{~mm}$ in width, and 1.5 $\mathrm{mm}$ in height were observed. They were whitish yellow in colour, firm in consistency, and not adherent below (Fig. 2).

Microscopically. On light microscopy the conjunctival stroma was highly infiltrated by lymphocytes in which were found various badly delimited nodules 


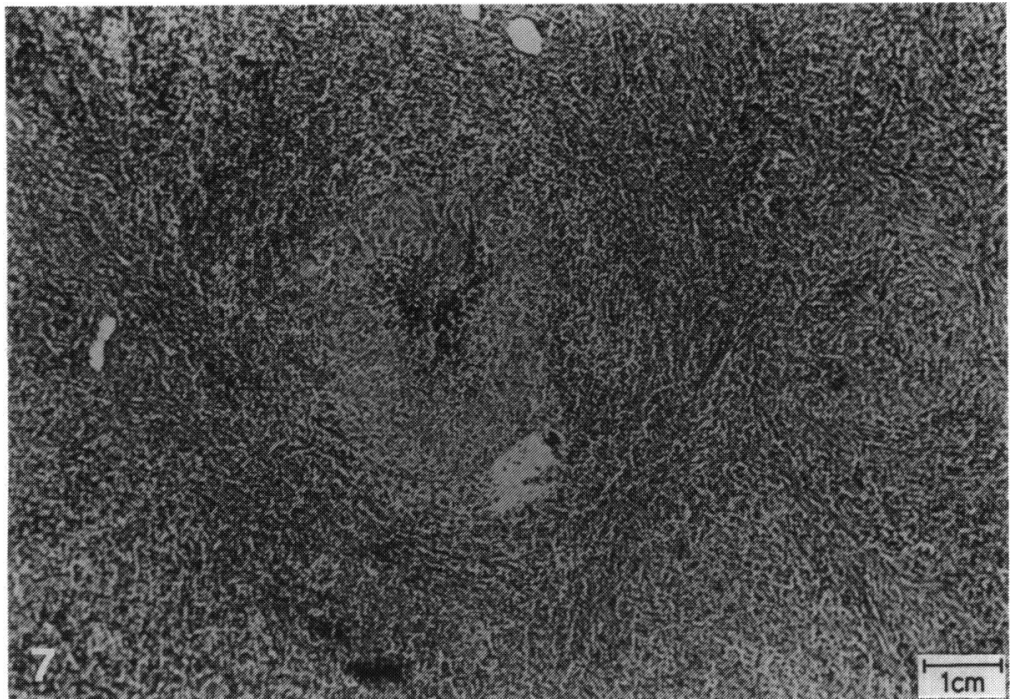

Fig. 7 Granuloma photographed within the pretragal adenopathy. $(H-E$, scale $=127 \mu m)$.

made up of epithelioid cells and sometimes of giant multinucleated cells of the foreign body type. Serial slides showed various structures-caterpillar hairs (Fig. 3), tracheal fragments, oenocytes (Figs. 4 and 5 ), and a grain of pollen (Fig. 6). Although the circumstances of the onset of this condition, the macroscopic appearance of the lesion, and its histological appearances were pathognomonic according to Malan, ${ }^{12}$ we wanted to ascertain whether the foreign bodies found on the slides did in fact come from processionary caterpillars.

\section{PATHOLOGY OF THE PRETRAGAL ADENOPATHY} Histological examination showed a ganglionic stroma with micro-abscesses surrounded by histiocytes (Fig. 7). The histological image was compatible with cat scratch disease.

\section{Morphology of the processionary caterpillar}

The caterpillars studied, Thaumetopoea pityocampa Schiff, were captured at the larval stage on a black pine (Pinus nigra) in mid November 1983. Scanning electron and light microscopic examination allowed us to compare and recognise the various foreign bodies found in the conjunctival swab.

\section{THE INSECT EYE AND URTICARIAL HAIRS}

Urticarial hairs are implanted on the facets of the insect 'mirror', * including two small posterior and two large anterior facets (Figs. 8 and 9). The hairs

*'Mirror' or group of papillae (Beille, 1896), cited by Pesce $\mathrm{H}$ Delgado A. Poisoning from adult moths and caterpillars. In: Bücherl W, Buckley EE, eds. Venomous animals and the venoms. New York: Academic Press, 1971; 3: 142. found elsewhere on the caterpillar body were not urticarial and did not become detached spontaneously. Experimental studies on the rabbit eye with hairs other than the urticarial ones of the insect eye did not provoke ophthalmia nodosa. ${ }^{13}$

\section{TRACHEAL FRAGMENTS}

The tracheal apparatus, highly developed in the caterpillar, is subdivided into a multitude of small tracheas, the smallest of which is intercellular. ${ }^{14}$

\section{Discussion}

In Switzerland ophthalmia nodosa is mainly caused by urticarial hairs of the pine processionary caterpillar. Their urticarial hairs, constituent elements of the 'mirror', measure from 0.08 to $0.16 \mathrm{~mm}$ depending on the age of the caterpillars. ${ }^{15}$ Contrary to what is generally thought, the hairs surrounding the 'mirror' do not play any part in the releasing of the hairs. When a 'mirror' opens, the hairs are carried away by the wind and break up at the slightest contact, thus releasing an unknown urticarial substance. ${ }^{16}$ When the urticarial hairs penetrate the human eye by an as yet unknown means, ${ }^{17}{ }^{18}$ they cause various complications, such as hypopyon ulceration, iritis, iridocyclitis, cataract, and even retinal detachment. ${ }^{19-21}$ The eyelid and conjunctival lymphatic drainage is carried out by means of the pretragal glands for the external part and by the submaxillary glands for the internal part. ${ }^{2}$ In this case the lesion situated in the conjunctival sac near the external angle is therefore related to the pretragal adenopathy, described as Parinaud's oculoglandular syndrome. However, so far as we know, ophthalmia nodosa has never been 
Fig. 8 Open mirror of the pine processionary caterpillar Thaumetopoea pityocampa Schiff (larval stage L4). Scanning electron microscopy. (Electron Microscopy Center of the Medical Faculty, Lausanne University. Scale $=1$ mm).

Fig. 9 Urticarial hairs. Enlargement of a bunch of hairs on the left upper facet of the mirror shown in Fig. 8. (Scale $=100 \mu \mathrm{m})$.
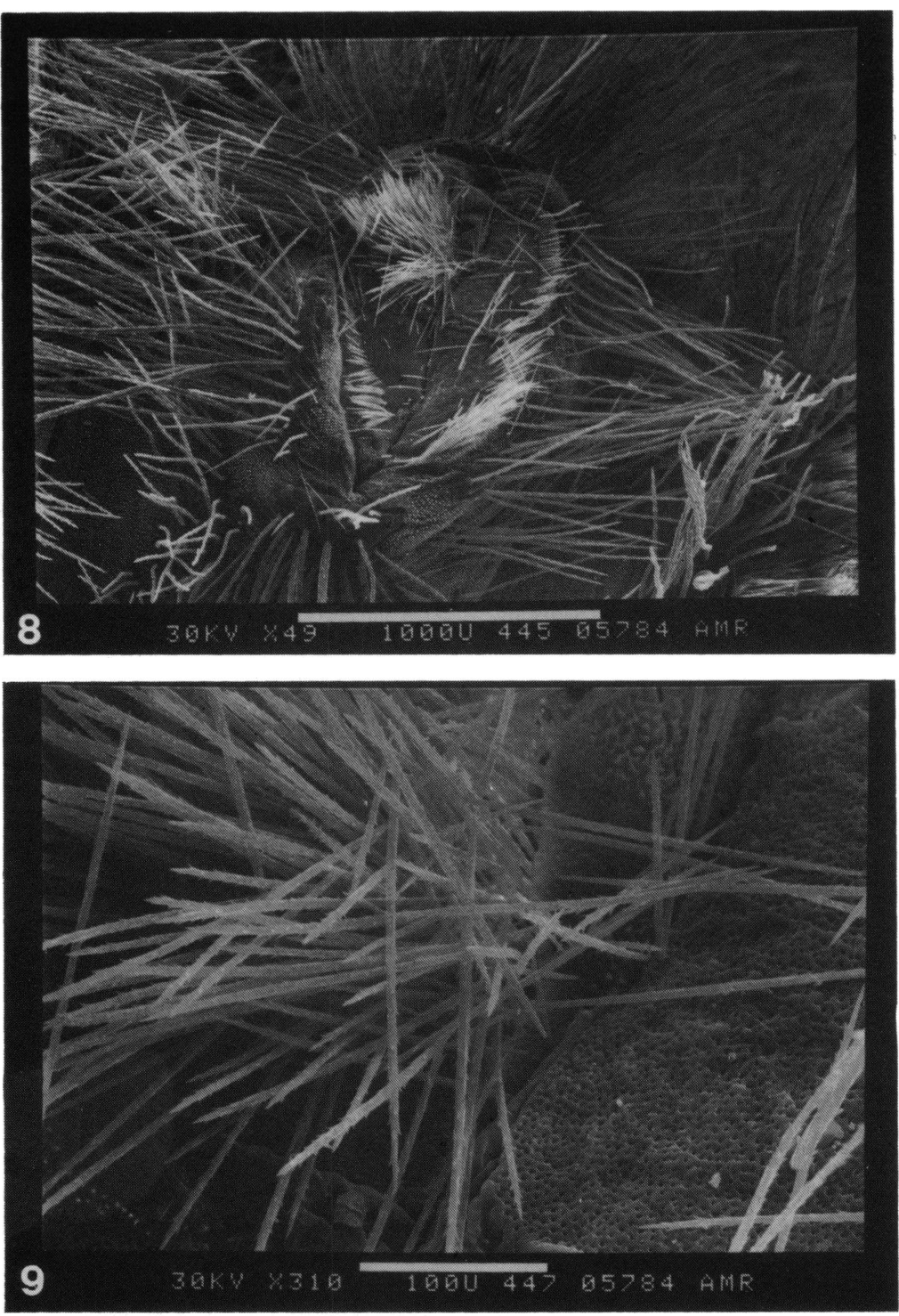

described in association with an oculoglandular syndrome, ${ }^{382324}$ nor has the oculoglandular syndrome, with cat scratch disease as its most frequent cause, ever been described as appearing later than the sixth week after the scratching. ${ }^{25-27}$ Thus we realise that pretragal adenopathy is related not only to caterpillar hairs but also to some other pathogenic element, such as tracheal fragments, oenocytes, pollen, the cat scratch disease agent, or another.

\section{TRACHEAL FRAGMENTS AND OENOCYTES}

It was possible to identify tracheal fragments and oenocytes found in conjunctival tissue through a review of the entomological literature ${ }^{14} 28-31$ and from a comparison between the conjunctival and caterpillar slides. Oenocytes are cells of ectodermal origin, usually found in chain formation on the caterpillar walls ${ }^{31}$ in the vicinity of the trachea ${ }^{14}$ The oenocytes produce lipoprotein, probably carried by oenocytoids. These lipoproteins are necessary for the formation of the caterpillar's cuticle. ${ }^{32}$ Are the oenocytes and their lipoproteins the responsible antigens or co-antigens in causing the adenopathy? If this were so, the association would probably be known, because when destroying a caterpillar nest one is exposed to hairs as wells as to fragments. 


\section{POLLEN}

Even though the patient had several types of allergyfor example, to penicillin and streptomycin-we think it most improbable that a black-pine pollen grain could be the cause of the oculoglandular syndrome. Clinical and laboratory tests possibly failed to reveal some other pathogenic agent, contracted by the patient at the same time or transmitted by the caterpillar fragments.

\section{OTHER PATHOGENIC ELEMENTS}

It is seldom that a second pathogenic agent is associated with the hairs of the processionary caterpillar. The only reported case was one described by Rhoner and Huber, ${ }^{33}$ who, after having enucleated an eye for aspergillosis, found a caterpillar hair in the vitreous body. In the case we present here mycological tests proved to be negative.

\section{CAT SCRATCH DISEASE}

The cause of cat scratch disease is unknown, but atypical bacteria, ${ }^{34}$ chlamydia, and a herpes-like virus $^{35}$ are possible. The scratches on the homolateral eyelid that the patient received six and a half months before the ophthalmia nodosa, the histological appearance of the adenopathy, and the presence of a positive antigen test to cat scratch disease all suggest the presence of this disease, whose causal agent, as in herpes infection, remains latent. So far as we know this report provides the first description of the association of ophthalmic nodosa and the oculoglandular syndrome of Parinaud.

We are very grateful to Ms Anne Fischer-Cassiot, who allowed us to consult her most interesting work on the processionary caterpillar, and to Mr Max Hachler for his advice, both working at the Federal Centre of Agronomic Research at Changins, and to Mr Alexander Cotty, of the Zoological Museum of Lausanne. We also thank Dr Robert Brun, lecturer at the Geneva Medical Faculty, for kindly giving us the cat scratch disease antigen, Ms Madeleine Martin for typing the article. Ms Françoise Sallaz for bibliographic research, Ms Letitia van der Linden for the English translation, and Dr Phillip Hendrickson, University Eye Hospital, Basle, for proof reading the text.

\section{References}

1 Havener WH, Falls HF, McReynolds WU. Burdock bur ophthalmia. Arch Ophthalmol 1955; 53: 260-3.

2 Saemisch Th. Die Krankheiten der Conjunctiva, Cornea und Sklera. In: Graefe-Saemisch, Handbuch der gesamten Augenheilkunde. Ed. 2. 1904; 5(1): 548.

3 Gredsted A. Beitrag zur Kenntnis der Verletzungen des Auges durch Klettenstacheln. $Z$ Augenheilkd 1928; 64: 357-65.

4 Bruhn AM. Klinische und experimentelle Untersuchungen über Augenschädigungen durch Klettenhaare. Klin Monatsbl Augenheilkd 1938; 101: 730-41.

5 Schön JMA. Augenentzündung durch eine Kieferraupe. Beiträge zur praktischen Augenheilkunde. Hamburg: Hoffmann und Campe, 1861: 183-4.

6 Pagenstecher $\mathrm{H}$. Interessante Präparate von Eindringen feiner Raupenhaare in die Conjunctiva und die Iris mit daran sich bildenden tuberkelartigen Knötchen. In: Donders FC, Hess W, Zehender W, eds. Bericht über die fünfzehnte Versammlung der Ophthalmologischen Gesellschaft, Heidelberg. Rostock: Universitäts-Buchdrucherei von Adler's Erben, 1883: 176-81.

7 Lawford JB. Ophthalmic nodosa. Trans Ophthalmol Soc UK 1895; 15: 210-29.

8 Watson PG, Sevel D. Ophthalmia nodosa. Br J Ophthalmol 1966; 50: 209-17.

9 Berman E. Un cas d'ophtalmia nodosa. Thèse, Univ. de Lausanne, Clinique Ophtalmologique, 1928.

10 Balachowsky AS. Famille des Notodantidae (=Ceruridae) In: Balachowsky AS, ed. Entomologie appliquée à l'agriculture, Lépidoptères 1972; 2: 1248-52.

11 Parinaud $\mathrm{H}$. Conjonctivite infectieuse paraissant transmise à l'homme par les animaux. Recueil Ophtal Soc d'Ophtal de Paris 1889; $11: 176$.

12 Malan P. Lésions oculaires dues aux poils de chenille. Clin Ophtalmol 1981; 3: 229-33.

13 Haluska FG, Puliafito CA, Henriquez A, Albert DM. Experimental gypsy moth (Lymantria dispar) ophthalmia nodosa. Arch Ophthalmol 1983; 101: 799-801.

14 Snodgrass RE. The oenocytes. In: Snodgrass RE, ed. Principles of insect morphology. New York: McGraw-Hill, 1935: 410.

15 Molin G de. Les 'miroirs' urticants de la processionnaire du pin. Rev zool agric appl 1963; 10-12: 107-14.

16 Fischer-Cassiot $A$. Essai de synthèse bibliographique sur la processionnaire du pin: Thaumetopoea pityocampa Schiff. Technicum Horticole de Lullier-Genève 1979: 1-119.

17 Ascher K. Raupenhaarverletzungen des Auges. Über den Mechanismus der Haarwanderung. Med Klin 1937; 33: 297-300.

18 Ascher KW. Mechanism of locomotion observed on caterpillar hairs. Br J Ophthalmol 1968; 52: 210.

19 Gailloud CI, Rabinowicz Th, Dufresne JJ. Catamnèse d'un cas d'ophtalmie nodulaire (par poils de chenilles). Ophthalmologica 1964; 147: 244-7.

20 Damand F. Raupenhaar-Vreitis durch Raupenhaare des Brombeerspinners. Klin Monatsbl Augenheilkd 1968; 153: 643-8.

21 Augebault J-Y, Mathieu M. Accidents oculaires par poils de chenille processionnaire du pin. Bull Soc Ophtalmol Fr 1974; 74: 373-9.

22 Warwick R. Lymphatics, In: Warwick R, ed. Eugene Wolff's anatomy of the eye and orbit. 7th ed. London: Lewis, 1981: 218.

23 Duke-Elder S. Irritant animal products In: System of ophthalmology. London: Kimpton, 1972: 14(2): 1196-202.

24 Chin GN, Hyndiuk RA. Parinaud oculoglandular conjunctivitis. In: Duane TD, Jaeger EA, eds. New York: Harper and Row, $1983 ; 4: 1-8$.

25 Margileth AM. Cat-scratch disease as a cause of the oculoglandular syndrome of Parinaud. Pediatrics 1957; 20: 1000-5.

26 Margileth AM. Cat-scratch disease: nonbacterial regional lymphadenitis. Pediatrics 1968; 42: 803-18.

27 Warwick WJ. The cat-scratch syndrome, many diseases or one disease? Progr Med Virol 1967; 9: 256-301.

28 Dewitz H. II. Wissenschaftlische Mitteilungen 1. Einige Beobachtungen, betreffend das geschlossene Tracheen-system bei Insectlarven. Zool Anz 1890; 13: 500-31.

29 Gonin J. Recherches sur la métamorphose des Lépidoptères (De la formation des appendices imaginaux dans la chenille du Pieris brassicae). Bull Soc Vaud Sci Nat 1894; 31: 89-139.

30 Weidner H. Beiträge zu einer Monographie der Raupen mit Gifthaaren. Zangewandete Entomologie 1936; 3: 432-84.

31 Gupta AP. Insect hemocytes. Development, forms, functions and techniques. London: Cambridge University Press, 1979: $109,234$.

32 Wigglesworth VB. Function of the oenocytoids. In: Gupta AP, ed. Insect hemocytes. Development, forms, functions and tech- 
niques. London: Cambridge University Press, 1979: 312-4. 33 Rhoner M, Huber O. Aspergillus als Ursache von Erblindung. Schweiz Med Wochenschr 1933; 63: 181-3.

34 Wear DJ, Margileth AM, Hadfield TL, Fischer GW, Schlager CJ, King FM. Cat-scratch disease. A bacterial infection. Science 1983; 221: 1403-5.
35 Corey L. Cat-scratch disease. In: Petersdorf RG, Adams RD, Braunwald E, Isselbacher $\mathrm{KJ}$, Martin JB, Wilson JD, eds. Harrisson's principles of internal medicine. 10th ed. New York: McGraw-Hill, 1983: 1176-7.

Accepted for publication 31 October 1985. 